\title{
Effect of enzyme preparations used for oak wood biocatalysis on the set of highly volatile components of aged brandy distillates
}

\author{
Kristina Reznichenko* and Galina Aleynikova \\ North Caucasian Federal Scientific Centre for Horticulture, Viticulture, and Winemaking, Krasnodar, \\ Russia
}

\begin{abstract}
The individual peculiarities of aged alcohol beverages are formed at the cost of technological factors, which is why it is so important to develop approaches aimed at improvement of the product quality and reduction of production costs. This can be achieved by more efficient and rational use of the natural potential of oak wood with the help of activation techniques based on biocatalysis. As far as the process of biochemical activation of oak wood used for brandy production has been understudied, investigations of the effect of enzyme preparations used for enzymatic catalysis of oak wood upon the quality of brandy distillates is of high interest at this time. We have studied the effects of the place of origin of oak wood, enzyme preparations, and treatment time upon the composition and accumulation dynamics of highly volatile components in brandy distillates. Every oak stave sample was separately treated by complex enzyme preparations with subsequent thermal exposure. Then the treated oak staves were poured up with young brandy distillate and stored for six months in tightly closed containers. As a result, data proving the effect of the place of origin of oak wood, enzyme preparations, and treatment time upon the qualitative and quantitative composition of highly volatile components of aged distillates were obtained.
\end{abstract}

\section{Introduction}

Enzymatic catalysis, or biocatalysis, is a leading research area of global biotechnology studying the regularities of enzymes' effect upon substrates. Enzymes isolated from live microorganisms, plants and animals have a unique ability to accelerate the biological processes coming with processing of various kinds of primary products and separate substrates in production technology of food products and additives, biologically active substances, medicinal compounds, light industry and agricultural products, and household chemical goods [1].

This research area refers to engineering enzymology, in particular industrial biocatalysis - a promising and ambitious branch of biotechnology that has got widespread use both in Russia and beyond. The global appearance of new highly-purified enzyme preparations

\footnotetext{
*Corresponding author: kokoko20@list.ru
} 
synthesized microbiologically from active natural producers, including with the use of genetic and cellular engineering, is conducive to development of industrial biocatalysis [1].

Over the past decade, the Russian Government and the national scientific community have been paying close attention to the development of new highly-efficient domestic technologies of production and use of biocatalysts by including projects related to biocatalytic processes into federal target-oriented scientific and engineering programs [2-3].

The winemaking technology is based on the regulation pf processes catalysed by primary product enzymes, its microflora, and cultural yeast and bacterial strains as fermentation agents [4]. At the same time, widely used are industrial preparations of hydrolytic enzymes of various specificity at the stages of obtaining grape juice, its preparation for fermentation, and wine stabilization [5-7].

Studies of the use of biocatalysts in woodworking industry present a particular interest for brandy production. N. Mokrushina et al. showed a possibility in principle of the use of natural strains of micromycetes for bioconversion of waste wood. The authors proposed to treat woodworking and forestry wastes with leaven containing cellulosolytic and ligninolytic strains of microorganisms of Fusarium and Aspergillus genera [8].

X.H. Wang, J.H. Ma developed a wood treatment technique to be used to reduce the total extract. It involves exposure of wood to one or a combination of several enzymes of lipase, esterase, pectinase, cellulase, laccase or hemicelluolase type at $35-70^{\circ} \mathrm{C}$ for the period of 10 to 72 hours [9].

In brandy production technology, Ye. Raider studied the activity of esterase, an extremely promising enzyme for etherification reactions and transformations of higher alcohols into ethers [10,11]. The author elaborated an immobilized esterase treatment technique for brandies to synthesize high-boiling ethers. Such treatment would decrease the content of higher alcohols, which can per se improve the quality of brandies. What is more, the nascent oenanthic ethers would refine and ennoble their bouquet and the taste [12].

The available scientific data let us assume that activation of oak wood used in brandy production may be performed with the use of enzyme-based biochemical activation.

With respect to that, we studied the natural microflora of oak wood for the purpose of maturation of distillates crafted from agricultural stock [13], and the impact of the method of preliminary oak treatment upon the structural faculties of oak wood [14]. We assessed the usefulness of enzymatic catalysis of oak wood to age agricultural distillates [15]. We also established the effect of the method of oak treatment upon the composition of the resulting aqueous-alcoholic extracts [16].

The aim of this thesis has been to identify the impact of enzyme preparations and the action time of oak of various origins upon the set of aged brandy distillates and upon tasting evaluation.

\section{Objects and methods of study}

As the objects of the study, we used brandy distillates aged for six months on biocatalysed wood of petiolate oak (Quercus robur) grown in the environs of the towns of Apsheronsk and Khadyzhensk, Krasnodar krai (region), and Maikop, the Republic of Adyghea.

Prior to ageing, each oak stave sample $(1.5 \times 1.5 \times 3.0 \mathrm{~cm})$ had been treated with complex enzyme preparations (Trenolin Super DF, Fructocim MA, San Super 240L, Fludase, and Glucosim L-400-C+) with subsequent thermal exposure (at $140^{\circ} \mathrm{C}$ for 45 hours). The duration of treatment with enzyme preparations was 1, 3, 4, 5 and 10 days, respectively. Thereupon, the biocatalysed oak staves were poured up with young brandy distillate based on specific surface area of $150 \mathrm{~cm}^{2} / \mathrm{dm}^{3}$ and stored for six months in tightly closed containers. 
The highly volatile components of aged brandy distillates were identified by gas chromatography (gas chromatograph "Kristall 2000,” Russia) (Company Standard STO 00668034-032-2011 "Brandy distillates. Standard technique for qualitative and quantitative composition of highly volatile fraction of aromatic components by gas chromatography," Krasnodar, 2011).

The tasting evaluation was performed on a one to ten scale according to GOST 320512013 "Wine products. Methods of organoleptic analysis."

\section{Results and discussion}

The obtained results proved the fact that there is a trend towards acetaldehyde enrichment in the distillates as the treatment time of oak wood originating from various habitats with enzyme preparations rises. The maximum values were recorded for the enzymatic treatment for 4 to 5 days (from 222.0 to $408.4 \mathrm{mg} / \mathrm{dm}^{3}$ ). When the duration of contact between staves and enzyme preparations grew to 10 days, acetaldehyde concentration went down to 126.3$254.7 \mathrm{mg} / \mathrm{dm}^{3}$. It can be assumed that best conditions for more intensive formation of acetaldehyde in distillates are formed in case of contact for 4 to 5 days between staves and enzyme preparations.

A similar trend was noted for acetic acid, whose maximum concentration values were observed in case of biocatalysis of oak wood for 5 days for all test variants. It was established that the enzyme preparation Fludase encouraged excessive accumulation of acetic acid by aged distillates (from $316.1 \mathrm{mg} / \mathrm{dm}^{3}$ in samples of Khadyzhensk oak up to $906.2 \mathrm{mg} / \mathrm{dm}^{3}$ in those of Maikop oak).

According to the obtained data, the concentration of ethyl acetate in the test distillates varied chaotically; at the same time, the content of ethyl acetate would go down in all samples if the duration of stave treatment was increased to 3-4 days. This fact can be explained by formation of conditions apt for hydrolysis of this ether, or by its entering into interesterification reaction. The highest accumulations of ethyl acetate were recorded when Apsheronsk oak was treated with Trenolin Super DF $\left(1172.4 \mathrm{mg} / \mathrm{dm}^{3}\right)$ and Glucosim L400-C+ (1270.2 mg/dm $\left.{ }^{3}\right)$, and Khadyzhensk oak - with Trenolin Super DF (1115.6 $\mathrm{mg} / \mathrm{dm}^{3}$ ) for 5 days. In all other test variants, the concentration of ethyl acetate was either on a par with or below control (without treatment).

While studying furfural, the concentration tended to increase with increasing duration of oak wood treatment. Such trend can be explained by the fact that as the duration of enzymes' impact upon oak wood increased, more monomeric compounds being parts of the wood's structural elements were formed - in particular, pentoses turning into furfural in the course of further thermal processing. At that, the highest concentration of furfural in the distillates was recorded when Khadyzhensk oak wood was treated with San Super 240L (40.0-45.0 mg/dm ${ }^{3}$ ) for 3-4 days.

As a result of oak wood treatment with Fructocim MA, San Super 240L and Fludase, the concentrations of isoamyl and isobutyl alcohols tended to decrease as the duration of treatment grew. At that, the concentrations of isoamyl and isobutyl alcohols were individual for oaks originating from a certain area, though the changes of concentrations took place within the same range as in case of the use of Glucosim L-400-C+ and Trenolin Super DF.

Methanol was accumulated in the distillates unevenly when the staves were treated with enzymes. For most samples, the minimum methanol concentration was identified when oak staves were activated for 3 days; the maximum concentration - when they were activated for 5 days (up to $722.8 \mathrm{mg} / \mathrm{dm}^{3}$ ).

For the purpose of identification and study of the main criterial components for which a substantial level of correlation with organoleptic evaluation had been established, statistical 
processing of the composition of highly volatile components of test samples was performed.

Table 1. Results of the correlation analysis.

\begin{tabular}{|l|c|}
\hline \multicolumn{1}{|c|}{ Component } & $\begin{array}{c}\text { Tasting evaluation } \\
\text { (correlation factor) }\end{array}$ \\
\hline Acetaldehyde & -0.34 \\
\hline Acetic acid & 0.06 \\
\hline Furfural & 0.13 \\
\hline Ethyl acetate & -0.23 \\
\hline Methyl acetate & 0.01 \\
\hline Ethyl formate & 0.18 \\
\hline Ethyl butyrate & -0.22 \\
\hline Ethyl valerate & 0.07 \\
\hline Isoamyl acetate & 0.03 \\
\hline Methyl caprylate & 0.00 \\
\hline Ethyl caprylate & -0.04 \\
\hline Propionic acid & 0.07 \\
\hline Isobutyric acid & 0.07 \\
\hline Butyric acid & -0.30 \\
\hline Isovaleric acid & 0.32 \\
\hline Methanol & -0.28 \\
\hline Isobutanol & 0.13 \\
\hline Isoamylol & 0.17 \\
\hline Sinapic aldehyde & -0.02 \\
\hline Coniferyl aldehyde & 0.00 \\
\hline Syringaldehyde & -0.09 \\
\hline Vanillin & -0.09 \\
\hline Syringic acid & 0.03 \\
\hline Vanillic acid & 0.03 \\
\hline Gallic acid & 0.00 \\
\hline & \\
\hline & \\
\hline
\end{tabular}

Based on correlation analysis aimed at establishing links between organoleptic evaluation and components of the chemical composition of brandy distillates, it was ascertained that a link existed between the degree of tasting evaluation and the concentrations of acetaldehyde, isovaleric acid, ethyl acetate, ethyl butyrate, butyric acid, and methanol (see Table 1 above).

Based on the regression analysis, it was established that such components as acetaldehyde (Beta=0.38), ethyl formate (Beta=0.42), and syringic acid (Beta=0.77) contributed positively to compilation of tasting evaluation (Fig. 1). By contrast, butyric acid was seen to exert a negative impact (Beta=0.33). 

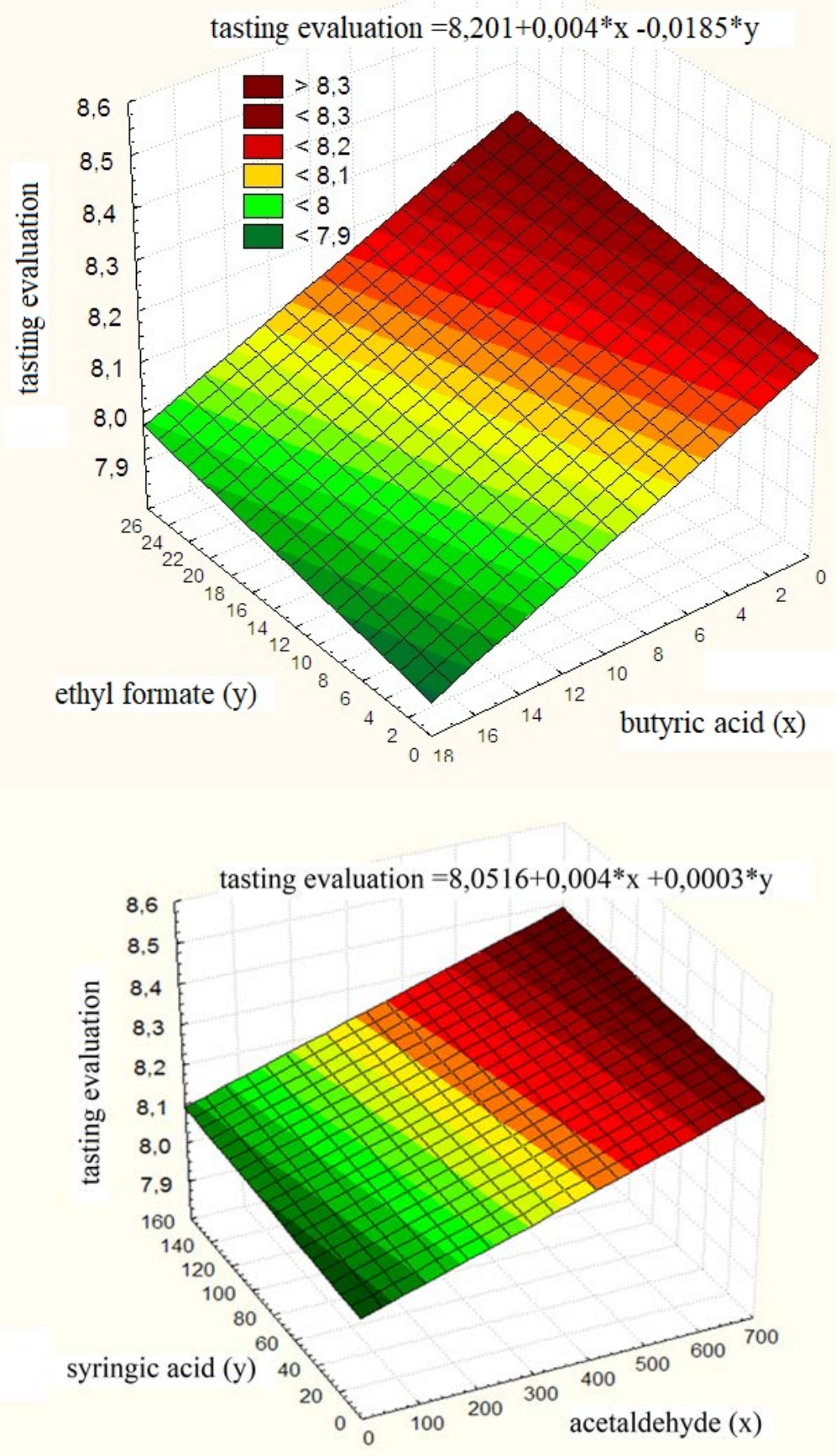

Fig. 1. Dependence of the tasting score: at the top - upon the level of concentration of ethyl formate and butyric acid; at the bottom - upon the level of concentration of lilac acid and acetaldehyde.

The statistical processing aimed at ascertainment of the impact of oak habitat, type of enzyme preparation, and duration of treatment upon the formation of tasting evaluation, 
performed with the help of multivariate analysis of variance has let us ascertain the following:

Out of the list of the analysed parameters, it was the type of enzyme preparation and the duration of treatment of oak staves that did affect tasting evaluation (Fig. 2). At the same time, no interrelation between wood habitat and tasting evaluation was revealed.

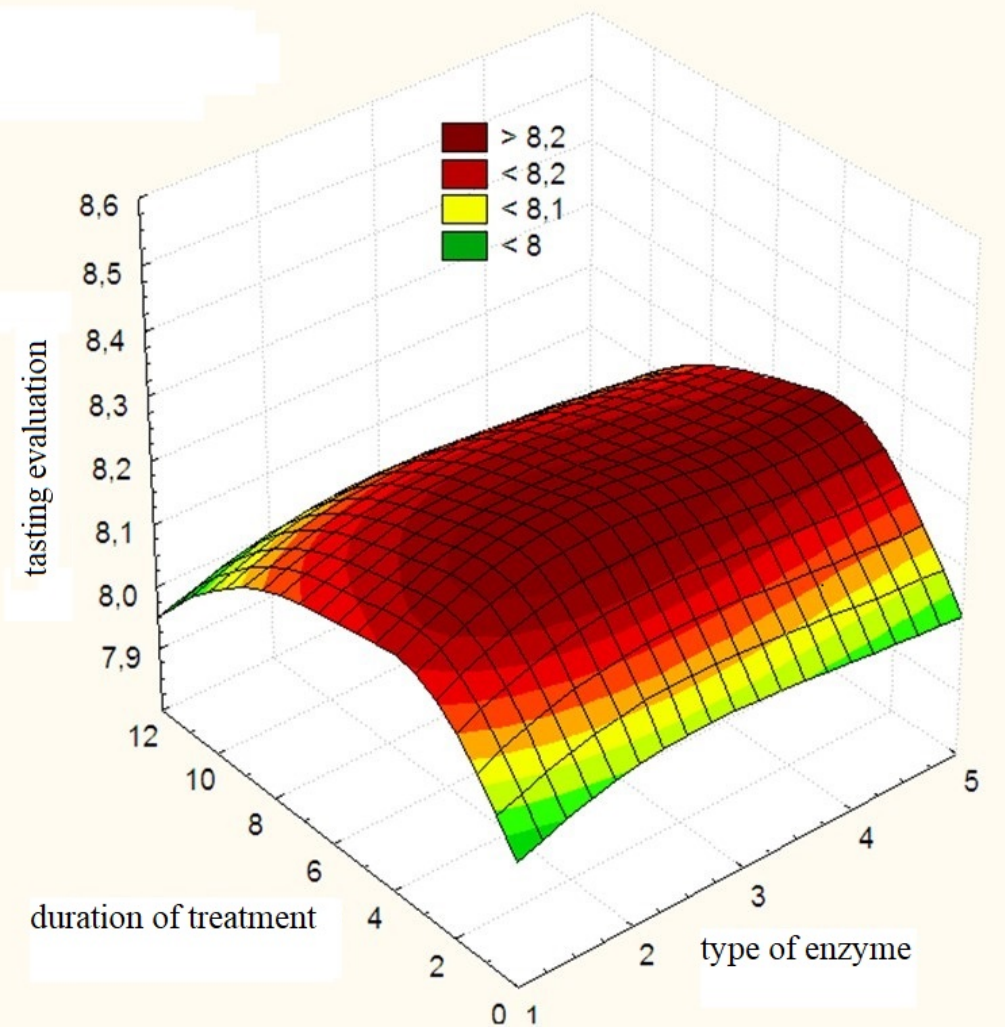

Fig. 2. Categorized graph of the level of tasting evaluation depending on the type of enzyme preparation and the duration of wood processing (type of enzyme: 1 - Trenoline Super DF, 2 Fructocyme MA, 3 - San Super 240L, 4 - Fludase, 5 - Glucosim L-400-C+)

\section{Conclusions}

As a result of the performed study, the impact of enzyme preparations and duration of treatment upon the composition of highly volatile components of distillates aged (matured) on biocatalysed oak wood (staves) originating from various habitats (environs of the towns of Apsheronsk, Maikop and Khadyzhensk, North-West Caucasus) was established.

When processed with enzyme preparations for 4-5 days, the concentrations of such volatile components as acetaldehyde, acetic acid, furfural, and methanol were observed to climb up, while those of isoamyl and isobutyl alcohols were seen to go down.

Based on correlation analysis aimed at establishing links between organoleptic evaluation and components of the chemical composition of brandy distillates, it was ascertained that a link did exist between the degree of tasting evaluation and the concentrations of acetaldehyde, isovaleric acid, ethyl acetate, ethyl butyrate, butyric acid, and methanol. 
Out of the list of the analysed parameters, it was the type of enzyme preparation and the duration of treatment of oak staves that did affect tasting evaluation. At the same time, no interrelation between wood habitat and tasting evaluation was revealed.

The study was carried out with the financial support of the RFBR and the Administration of the Krasnodar Territory in the framework of the scientific project No. 19-416-233021

\section{References}

1. G.N. Rumiantseva, N.I. Dunchenko, Biocatalysis: the concept and practical use. Student Manual. (Moscow: DeLi Print, 2010).

2. Ye.A. Zaitseva, T.A. Osipova, Vest. Mosc. Un. Ser. 2. Chemistry. Vol. 43. No. 6. P. 340-344. (2012).

3. Ye.A. Zaitseva, T.A. Osipova, Mosc. Un. Chem. Bul. Vol. 47. No. 1. P. 4-14 (2006).

4. C. Li, J. Zhou, G. Du, J. Chen, Sh.Takahashi, S. Li, Biotech. Adv. Vol. 44, 107630 (2020), https://doi.org/10.1016/j.biotechadv.2020.107630

5. W.-X. Sun, K. Hu, J.-X. Zhang, X.-L. Zhu, Y.-Sh. Tao, Food Chem., Vol. 245, P. 1248-1256 (2018), https://doi.org/10.1016/j.foodchem.2017.11.106

6. A. A. Borazan, B. Bozan, Food Chem., Vol. 138, Is. 1, P. 389-395, (2013), https://doi.org/10.1016/j.foodchem.2012.10.099

7. A. C. Camargo, M. A. B. Regitano-d'Arce, A. C. T. Biasoto, F. Shahidi, Food Chem., Vol. 212, P. 395-402, (2016), https://doi.org/10.1016/j.foodchem.2016.05.047

8. T.S. Mokrushina, T.S. Tarasova, I.V. Darmov, Proc.of Sam. Res. Cen. of the Rus. Ac. of Sc., Vol. 11, No. 1, p. 228-232. (2009). https://www.elibrary.ru/item.asp?id=12876921

9. X.H. Wang, J.H. Ma, C.L. Jiang, W.D. Jr. Brown Treatment of wood chips using enzymes. WO2007035481 (A1, 2007).

10. Ye. Yu. Raider, D.T. Mirzarakhmetova, Prod. of Alc. and Alc. Bev. No/ 4, P. 28-29. (2011). https://www.elibrary.ru/item.asp?id=21152580

11. Ye. Yu. Raider, D.T. Mirzarakhmetova, J. of Res. Pub. of PhD Stud., No. 6, P. 67-69. (2011). -https://www.elibrary.ru/item.asp?id=21152580

12. Ye. Yu. Raider, Ext. abs. of PhD dis. (Tashkent, 2011).

13. K.V. Reznichenko, Mat. of the Int. Sc. Conf. P. 198-200. (2019). https://www.elibrary.ru/item.asp?id=39154188

14. K.V. Reznichenko, M.V. Antonenko, G.Yu. Aleinikova, O.P. Antonenko, Ye. V. Globa, Plodovodstvo i vinogradarstvo Yuga Rossii (Fruit Farming and Viticulture in South Russia), 60(6.), P. 163-171, (2019). https://doi.org/10.30679/2219-5335-2019-660-163-171 https://www.elibrary.ru/item.asp?id=41336746

15. K.V. Reznichenko, M.V. Antonenko, G.Yu. Aleinikova, O.P. Antonenko, Ye. V. Globa, // Nauchnye Trudy SKFNTsSVV (Transact. of the North Caucasus Fed. Sc. Centre of Horticulture, Viticulture and Winemaking), P. 293-299, (2020). https://doi.org/10.30679/2587-9847-2020-29-293-299.

16. K.V. Reznichenko, M.V. Antonenko, G.Yu. Aleinikova, O.P. Antonenko, Ye. V. Globa, Russkiy Vinograd (Rus. Grapevine), Vol.10. P. 132-140, (2019). https://doi.org/10.32904/2412-9836-2019-10-132-140 